Prace Literackie LIX

Wrocław 2019

https://doi.org/10.19195/0079-4767.59.6

\author{
GABRIELA IWIŃSKA \\ ORCID: 0000-0001-7151-9350 \\ Uniwersytet Wrocławski
}

\title{
Śmierć odsunięta w nieskończoność. Filozofowanie Edwarda Stachury na temat czasu, śmierci i wieczności
}

Ziemowit Fedecki, odnosząc się do ostatniego etapu twórczego Stachury, głównie do Fabula rasa, pisał, że poeta nie zdobył się w ostatnich utworach na „przemyślenie dorobku filozoficznego minionych epok, ani też na próbę polemiki z jakimkolwiek nurtem współczesnej myśli filozoficznej czy społecznej”'. Sytuuje ów krytyk takie próby wśród tych, które nie wymagają wysiłku intelektualnego odbiorcy, tym samym spychając tę literaturę w kategorię rozwodnienia, niekonkretność oraz sprowadzając do zaledwie kilku prawd uniwersalnych. Największą wartość spośród wszystkich dzieł pisarza Fedecki upatruje w Kropce nad ypsylonem i, opierając się właściwie na tym jednym dziele, konkluduje, jak świetnym poetą był Stachura. Podobnie jest z narosłą wobec autora Siekierezady legendą, która też nie staje się pomocna przy próbie głębszej eksplikacji tej twórczości, o czym pisze Michał Januszkiewicz:

Nazwisko Stachury pojawia się zwykle wśród młodych kontestatorów - Hłaski, Bursy czy Wojaczka, a narosła wokół autora Siekierezady legenda i swoista moda powodują, że biografia przesłania literaturę, którą tworzył².

Podobny pogląd reprezentuje także Anna Al-Araj, zaczynając swój artykuł od słów:

${ }^{1}$ Z. Fedecki, Moda na Stachure, [w:] Kaskaderzy literatury. O twórczości i legendzie Andrzeja Bursy, Marka Hłaski, Haliny Poświatowskiej, Edwarda Stachury, Ryszarda Milczewskiego-Bruna, Rafała Wojaczka, red. E. Kolbus, Łódź 1986, s. 274.

2 M. Januszkiewicz, Od egzystencjalizmu do mistyki: o prozie Edwarda Stachury, „Pamiętnik Literacki" 85, 1994, z. 4, s. 96. 
Zasadniczą motywacją do podjęcia namysłu nad charakterem twórczości prozatorskiej Edwarda Stachury jest przekonanie o niesprawiedliwości i pobieżności osądu — podzielanego przez wielu krytyków - na temat znaczenia dorobku tego pisarza ${ }^{3}$.

Być może próba zrozumienia toku myślenia Edwarda Stachury o czasie, śmierci i wieczności stanie się zachętą do ponownego, a tym samym nowego odczytania tej twórczości.

Teksty autora Całej jaskrawości to ciągłe zmaganie się z przemijalnością. Oczywiście pierwszym punktem zaczepienia się o jakieś „zawsze” to zostanie zapamiętanym ze względu na spuściznę literacką. Ale, jak to bywa u Stachury, jego „podstawą buntowniczego »tak« jest konsekwentne dążenie do utożsamienia słowa i czynu"4, toteż Stachura rzeczywiście szukał odpowiedzi tam, gdzie słowo łączy się z rzeczywistością, a nie tylko zostaje na literackim gruncie. „Sted porusza się w obszarze elementarnych pytań egzystencjalnych i nie interesują go zdawkowe odpowiedzi"5. Dlatego do znalezienia odpowiedzi na temat tego, czym jest wieczność i nieśmiertelność, przygotowuje się przez większość swoich dzieł, próbując uspójnić materię słowa z filozofią, a tym samym z pewnego rodzaju postawą i oczekiwaniami. Owo poszukiwanie jakiegoś ,zawsze” Stachura niekiedy opiera na ontologii:

A więc nic. Co to jest nic? A więc nic to nie jest to, co nie jest. Co to jest, to co nie jest? To, co nie jest, to jest dopełnienie tego, co jest. To, co jest, nie byłoby bez tego, co nie jest. Jak można by powiedzieć, że coś jest, nie mogąc powiedzieć, że to coś nie jest, że tego czegoś kiedyś nie było lub że to coś może kiedyś nie być? To, co nie jest, nie „byłoby” bez tego, co jest. Jak można by powiedzieć, że coś nie jest, nie mogąc powiedzieć, że to coś jest, że to coś kiedyś było lub że to coś może kiedyś być? Nie ma jest bez nie jest; nie ma nic jest bez jest; nie ma — „nic”. Wielka polana to jest to: zobaczenie, że nie ma „nic”. Coś, co jest, i coś, co nie jest - TO SAMO ${ }^{6}$.

Cały fragment został usytuowany wokół „niczego”, które jest efektem „po czymś” lub też zapowiedzią „,przed”. Takie są dwie opozycyjne możliwości, jednak Stachura podkreśla, że „to, co jest” i „to, co nie jest”, te dwa stany, są mocno z sobą sprzężone. Są od siebie zależne. Dostrzega, że nie istnieje coś takiego jak całkowite „nic”. Udowadnia to już w pierwszych zdaniach — nie można powiedzieć, że coś nie istnieje, bez świadomości tego, że to coś istniało wcześniej albo istniało w podobnych okolicznościach gdzieś indziej. Nasza podświadomość nie rozumie partykuły „nie” — dla ludzkiego umysłu myśleć o czymś, a zarazem nie myśleć o czymś, to to samo. Mało tego, jeśli człowiek wyda sobie samemu komendę „nie myśl”, to umysł wykona przeciwną pracę ${ }^{7}$. Nie jest możliwe wyrażenie „nie ma nic” bądź „nie ma kogoś/czegoś”, ponieważ ludzki mózg, odwrotnie, jest

${ }^{3}$ A. Al-Araj, Twórczość prozatorska Edwarda Stachury w świetle tradycji literackiej i filozoficznej, „Pamiętnik Literacki” 108, 2017, z. 4, s. 49.

${ }^{4}$ M. Januszkiewicz, op. cit., s. 100.

5 Ibidem, s. 99.

${ }^{6}$ E. Stachura, Wszystko jest poezja. Opowieść-rzeka, red. H. Bereza, Z. Fedecki, K. Rutkowski, t. 4, Warszawa 1984, s. 128.

${ }^{7}$ https://ilemnietoja.pl/nerwica/bajka-o-kwiecie-paproci/ [dostęp: 11.08.2019]. 
zdolny zobaczyć „coś” lub „kogoś”. Idąc tym tropem, można wysnuć wniosek, że czegoś nie ma, ponieważ zawsze zostaje pamięć, kiedy ten ktoś/to coś było. Tym właśnie nie jest „,nic” według Stachury — nie jest pustką. „Nic” definiowane jest przez autora także na podłożu metafizycznym - chodzi o nieprzerwane trwanie nie tylko ludzi, lecz także zwierząt i roślin. Czy skoro nie istnieje „nic”, to czy w ramach pewnego „wiecznego czegoś” istnieje jakakolwiek forma śmierci?

To jedno z najważniejszych pytań, nad którym chciałabym rozwinąc dalsze rozważania. Michał Januszkiewicz doszukuje się w postawie Stachury wobec tego tematu buntu:

Bunt eschatologiczny, bunt przeciw nicości to najostrzejszy krzyk pisarza. To już nawet nie krzyk, nie niemy sprzeciw, lecz walka na śmierć i życie — w znaczeniu dosłownym. Walczyć więc trzeba — przeciw śmierci, która wprowadza do życia element nicości ${ }^{8}$.

Rzeczywiście, Stachura buntuje się przeciwko śmierci. Śmierci rozumianej szeroko - jako tej, która przerywa i kończy wszystko definitywnie, a zatem zarówno tej biologicznej, jak i tej mentalnej. Wyraża to explicite na łamach wielu swoich utworów. We Wszystko jest poezja robi to autointertekstualnie, powołując się na Cała jaskrawość:

Zwróćmy uwagę na to, gdzie Edmund Szerucki umieszcza, umiejscawia wieczność, kiedy mówi o „całej jaskrawości życia i śmierci i balansującej między tymi wieczności”. Wieczność umiejscawia pomiędzy życiem a śmiercią. W ten sposób śmierć zostaje odsunięta w nieskończoność. Nie ma śmierci ${ }^{9}$.

W tym fragmencie czymś, co oddala śmierć, jest wieczność, która rozłącza dwa, wydawałoby się spójne, etapy — życie i śmierć. Wieczność jest pośrodku. Później Stachura wyznaje w Fabula rasa, że

Całe twoje życie jest bezustanną ucieczką przed śmiercią, do której wszakże, cokolwiek byś nie czynił, nieubłagalnie, nieodwracalnie, nieodwołalnie zbliżasz się. Całe twoje życie jest bezustanną ucieczką od siebie do siebie, bo nie możesz uciec gdzie indziej ${ }^{10}$.

Jest to pewna reinterpretacja własnych poglądów ze Wszystko jest poezja — nie tyle przeciwstawienie się swoim wcześniejszym tezom, ile ich zakwestionowanie. Stachura, można powiedzieć, poddaje krytyce swoje dotychczasowe myślenie, piętnując je jako „ucieczka”. W „opowieści-rzece” ta ucieczka nie jest wcale tą „od siebie do siebie”, tylko tą wyrażaną w sposobie nowego definiowania takich pojęć jak czas, przemijalność, wieczność czy nieśmiertelność. W Fabula rasa śmierć jest również rozumiana jako podróż w głąb siebie. Z kolei w Oto Stachura radzi: „Szukaj tej śmierci, co jest poznaniem siebie, co jest dodennym ujawnieniem skrytej świadomości, co jest całkowitym odsłonięciem się, co jest

${ }^{8}$ M. Januszkiewicz, op. cit., s. 102.

${ }^{9}$ E. Stachura, Wszystko..., s. 169.

${ }^{10}$ E. Stachura, Fabula rasa. Z wypowiedzi rozproszonych, red. H. Bereza, Z. Fedecki, K. Rutkowski, t. 5, Warszawa 1984 s. 67. 
nagością $[\ldots]^{\prime \prime 11}$. Wszystkie te trzy teksty są dowodem na to, jak bardzo Stachura próbował oswoić się ze słowem ,śmierć”, na ile sposobów próbował ją redefiniować, pojąć czy nawet podważyć. Za każdym razem jest ona czymś nieco innym, ale nigdy nie zostaje wyrażona bądź utożsamiona z jakimkolwiek końcem.

Niezgoda, a w zasadzie niewiara w istnienie śmierci prowadzi refleksję Stachury także w innym jego utworze, Siekierezadzie: „Gdybym wierzył w to, że umrę, to życzyłbym sobie $\mathrm{w}$ takiej właśnie trumnie być pogrzebanym [...], a poczynając od tego, że wierzę w to, iż umrę. Bo n i e wi e r zę [wyr. — G.I.]"12. Dla Stachury nie istnieje coś takiego jak ,nic”, nie istnieje żaden akt odchodzenia, bo autor nie zakłada zasadności uznania istnienia końca. Analogiczne słowa można również odnaleźć w Całej jaskrawości:

Nigdy nie uwierzę w to, że kiedy przestanie telepać mi tamto, gdzie rękę teraz trzymam po lewej stronie piersi, kiedy przestanie bić mi serce, kiedy ono przestanie być, ja wtedy też przestanę być i wszystko się skończy ${ }^{13}$

oraz następny fragment pochodzący z tego samego dzieła:

Kiedy umrę, w co nie wierzę, więc kiedy umrę, nie ja będę muskał życie, ale życie muśnie mnie, kiedy ktoś żywy o mnie pomyśli. Może ty, który w tej chwili nienarodzony jeszcze, ty, który w tej chwili, już narodzony, pomyślałeś o mnie w tej chwili, kiedy mnie już nie ma ${ }^{14}$.

Nieśmiertelność, nieskończoność, wieczność. Takimi dyrektywami Stachura posługuje się w obliczu myślenia, pisania o czasie. Znów, warto zauważyć, pojawia się słowo „wierzyć”. To nie jest próba rozumowego, racjonalnego postrzegania autora Całej jaskrawości. To jest pewnego rodzaju stan wyjścia poza umysł. Konstatację tę oparłam już we wcześniejszym artykule ${ }^{15}$ na myśli Kierkegaarda: „wiara właśnie tam się zaczyna, gdzie myślenie się kończy”16. Tę niezgodę na śmierć podobnie odczytuje Michał Januszkiewicz, pisząc w perspektywie buntu, który nazwał eschatologicznym: „Wyrasta on [ten bunt — przyp. G.I.] ze sprzeciwu wobec śmierci (nicości) i z drugiej strony dąży do afirmacji wartości jej przeciwstawnej — życia" 17 .

Stachura we Wszystko jest poezja wyzbywa się mówienia o tym, że coś jest lub coś nie jest. Myśląc o sobie, o uchronieniu się przed śmiercią, proponuje takie rozwiązanie leksykalne, które miałoby zapełnić pewną lukę w języku:

Zapomniał ten albo ci, którzy wymyślili czasy proste i czasy złożone: praesens, imperfectum, perfectum, plusquamperfectum, futurum I, futurum II, inne czasy złożone, zapomnieli oni, którzy

11 E. Stachura, Oto, [w:] idem, Wiersze pozostate, s. 98.

12 E. Stachura, Siekierezada, Toruń 2011, s. 125.

13 E. Stachura, Cała jaskrawość, Toruń 2012, s. 15.

14 Ibidem, s. 82.

15 G. Iwińska, Próba wtasnej filozofii we „Wszystko jest poezja” Edwarda Stachury, „Prace Literackie" 58, 2018, s. 315-323.

${ }^{16}$ S. Kierkegaard, Bojaźń i drżenie, przeł. J. Iwaszkiewicz, Warszawa 1982, s. 55.

${ }^{17}$ M. Januszkiewicz, op. cit., s. 104. 
byli, więc są i będą, zapomnieli o jednym czasie, wieczystym, infinitus. Który odmienia się tak: ja być, ty być, on być, my być, wy być, oni być ${ }^{18}$.

„Być”. Po prostu. Nie ma tu żadnej przesłanki o określeniu czasu. Nie ma czegoś takiego jak czas przeszły, teraźniejszy czy przyszły. A tym samym w „być” nie odnajdziemy ani początku, ani końca. To nieskończoność trwania. Tak samo odczytywała te tropy Anna Al-Araj, porównując Stachurę z Białoszewskim: „łączy tych dwóch twórców także pragnienie przezwyciężenia czasu pojmowanego linearnie. W chęci oddania »wiecznego teraz«, konstytuującego się na oczach czytelnika. Stachurze pomaga - respektujący równoległość zdarzeń - czas »infinitus «"19. W takim razie „być”, w kontekście człowieka, trzeba rozumieć jako życie bez początku ani końca. Ta teoria jednak implikuje przeciwstawne co do śmierci pytanie - czy istnieją narodziny człowieka? I kolejne pytanie: czy fakt, że nie pamiętamy swoich narodzin, sprawia, że nie możemy być pewni jakiegokolwiek początku? Podobnie jest ze śmiercią. Oba punkty są rozmyte. Owszem, jesteśmy świadomi, bądź inaczej, możemy być świadomi własnej agonii, ale nie jest to samo centrum śmierci. To życie, kończące się, ale wciąż życie. Poza tym nie jest wiadome, co następuje po, jak też przed życiem. To, czym operuje świat, to jedynie przesłanki wynikające $\mathrm{z}$ różnych kultur, religii. Można w takim razie zgodzić się ze Stachurą w tym, że nie istnieje ani początek, ani koniec. Dlatego wszystko dla niego jest wiecznością i z tego względu tworzy formę bezokolicznikową „być”. Teksty Stachury w ogóle są przesycone różnymi bezokolicznikami. Taki typ pisania nie spotykał się z aprobatą krytyki. Grażyna Borkowska pisze o tym krótko: „Zdecydowanie lepiej wypada Stachura-poeta w przekładach. Jako autor oryginalny często kuleje. Gubi go fatalna składnia, przejęte Bóg wie skąd upodobanie do form bezokolicznikowych" ${ }^{20}$. Owo „upodobanie”, czynione konsekwentnie przez większość tekstów, niesie w sobie ładunek filozoficzny. Jeśli się nie wniknie głębiej w strukturę tekstu, w jego filozoficzne podszycie, można to odebrać jako bełkot.

[T]am gdzie jest życie, to w jakiś sposób wszystko jest życiem... że tam gdzie jest życie, to życie jest w mocy wszystko ożywić... albo wyjaśnić, umieścić w treści i utrzymać w tej treści to, że nie-życie, nie-nasza-forma-życia nie jest śmiercią. Nie widzę dla życia, nie może być dla życia godniejszego „zadania” niż właśnie to. Nieśmiertelność ${ }^{21}$.

Barbara Czochralska twierdzi, że wizja Stachury „brała swój początek z Początku Świata”, że jego poznanie miało wymiar transcendentalny, wykraczało poza doświadczenie, chciało odkryć istotę rzeczy ${ }^{22}$. Trawestując Genesis, można by wysnuć wniosek, że Stachura próbuje powiedzieć: na początku było życie,

18 E. Stachura, Wszystko..., s. 129.

19 A. Al-Araj, op. cit., s. 55.

${ }^{20}$ G. Borkowska, Edward Stachura: Nie wszystko jest poezja, [w:] Sporne postaci polskiej literatury współczesnej: następne pokolenie, red. A. Brodzka, L. Burska, Warszawa 1995, s. 126.

${ }^{21}$ E. Stachura, Wszystko..., s. 214.

22 B. Czochralska, Ktoś spoza planety. Spotkania z Edwardem Stachura, Kraków 2014, s. 99. 
które dało życie wszystkim pozostałym rzeczom. W przytoczonym fragmencie nie dość, że sprzeciwia się istnieniu śmierci, to próbuje dowieść, że istnieje jakieś życie po życiu, które nie jest śmiercią. Głosi, że jedynym zajęciem dla życia jest nieśmiertelność, trwanie nieskończenie. Opozycyjnie do tezy Pascala: „Nic nie jest tak ważnym dla człowieka jak jego stan; nic nie jest dlań równie straszliwym jak wieczność" 23 . Potem, w tak zwanym mistycznym okresie, Stachura będzie bliżej tezy Pascala niż swojej. Michał Januszkiewicz, podążając tym samym tropem i badając stosunek Stachury do śmierci i życia, dochodzi do takich wniosków w kontekście Całej jaskrawości:

Nie ma wątpliwości, iż bohater powieści przeżywa objawienie religijne [...]. Edmund Szerucki z Całej jaskrawości spostrzega w swym olśnieniu, że natura wszechrzeczy pozostaje ta sama, a sprawy takie, jak dobro i zło, życie i śmierć, to nic innego niż tylko sztuczne — i tym samym fałszywe — pojęcia stworzone przez człowieka. Oto typowe dla kultury europejskiej myślenie dualistyczne leży u podstaw cierpienia, implikuje bowiem konflikt, walkę ${ }^{24}$.

Stachura, chcąc sobie oszczędzić tego cierpienia, usuwa w swojej filozofii pojęcia jak „nic” i ,śmierć”. Wizja końca swojego i innych ludzi jednak autora nie opuszcza. Stąd cały bunt i przeciwstawienie się temu, co wydawałoby się naturalne. W tekście Wszystko jest poezja, obok fragmentu o tym, że życie wszystko ożywia i jego celem jest nieśmiertelność, znajduje się jakby pewne wytłumaczenie takiego toku myślenia: „Bo inaczej nie sposób, absolutnie nie sposób jest żyć z tą straszliwą świadomością, z tym winnym-li-niewinnym wyrzutem sumienia, że się żyje, kiedy tylu, tylu, tylu umarło i nieustannie umiera"25. Prawie identyczne zdanie znajduje się w słynnym tekście $J a k^{26}$. Stachurze trudno jest pojąć nie tylko swoją, ale każdą inną śmierć. Wszystko, o czym pisze w „opowieści-rzece” jest próbą zrozumienia tego, dlaczego ludzie umierają. To napawa go lękiem, który został wyrażony dosłownie:

Ze strachu przed śmiercią w dużej mierze (żeby jej nie przegapić; żeby nie zginąć z zamkniętymi oczami, w nieświadomości, w tym stanie pół-życia, tak jakbym się bał, że ten stan, do którego przejdę po śmierci, będzie też tylko stanem pól-czegoś, jeżeli przekroczę tę — być może nie istniejącą - granicę w nieświadomości, w tym stanie pół-życia). I w ogóle, i w ogóle. Od niepamiętnych czasów bałem sięe27.

Stachura boi się, że to, co nastąpi „po”, będzie „też tylko” [sic!] stanem pół-czegoś. Czyli — wyjaśniając — nic się nie zmieni. Trzeba zwrócić uwagę na zwrot: ,jeśli przekroczę tę granicę w nieświadomości”. Zatem to nie tylko strach przed śmiercią biologiczną, przed rozkładem ciała, lecz także obawa przed stratą

${ }^{23}$ B. Pascal, Myśli, przeł. Boy-Żeleński, https://wolnelektury.pl/katalog/lektura/pascal-mysli. html [dostęp: 2.09.2019].

${ }^{24}$ M. Januszkiewicz, op. cit., s. 107-108.

${ }^{25}$ E. Stachura, Wszystko..., s. 214.

${ }^{26}$ jak suchy szloch $w$ te dżdżysta noc/jak winny-li-niwinny sumienia wyrzut/ze się żyje gdy umarło tylu tylu tylu, [w:] E. Stachura, Wiersze, Torun 2002, s. 123.

27 E. Stachura, Wszystko..., s. 236. 
świadomości, przejściem do stanu — no właśnie — „niczego”. Ten strach pokrewny jest z myśleniem Pascala, którego Stachura też często w swoich tekstach przytacza, a który jednak bardziej dopatruje się nadziei w drugim życiu, niż się go obawia:

Nie masz nic prawdziwszego i bardziej przerażającego. Udawajmy zuchów, ile chcemy; oto koniec, jaki czeka najpiękniejszy żywot w świecie. Niech się kto zastanowi nad tem, i niech potem powie, czy nie jest niewątpliwem, że jedyne dobro w tem życiu tkwi jeno w nadziei innego życia; że jesteśmy szczęśliwi jedynie w miarę jak się zbliżamy do niej, i że, tak jak nie będzie już nieszczęść dla tych którzy mieli zupełną pewność wieczności, tak niema szczęścia dla tych, którzy nie mają o niej żadnej wiedzy ${ }^{28}$.

Pascal w drugim życiu upatruje nadzieję, natomiast Stachura bardziej się obawia tego, co będzie w tym drugim życiu, niż szuka w nim ukojenia, chęci posiadania lepszego. Tak jak wspomniano - wprost przeciwnie, on się boi drugiego życia. Tego, że znów będzie niezadowolony.

Inaczej ugruntował się późniejszy światopogląd Stachury w Fabula rasa. Do teorii czasu z Wszystko jest poezja opozycyjnie nawiązują słowa: już minął.

— Jest tylko jeden czas: przeszły. Cały czas jest czasem przeszłym. Innymi słowy, cały czas

— Jakże to? A czas teraźniejszy? A czas przyszły?

- Czas teraźniejszy jest przeszłością odpowiednio modyfikowaną. Modyfikowaną według schematów, modeli, matryc, szablonów będących w przeszłości.

Co zaś tyczy się czasu przyszłego, nigdy go nie ma. Dlaczego? Bo jest już w przeszłości. Przyszłość jest tylko projekcją przeszłości ${ }^{29}$.

Stachura przeformułowuje swoje dotychczasowe poglądy filozoficzne. Nie ma już „być”, które było zakorzenione w wieczności, ponieważ w okresie mistycznym Stachura przesuwa je w przeszłość. Wówczas to jedyny możliwy czas. Wszystko inne jest jedynie, jak pisze, projekcją. Pocieszenie polega na tym, że Stachura pisze „Stulecia, milenia, miliony, miliardy, miriady lat, wszystkie czasy, absolutnie wszystkie czasy: przeszłe i tak zwane przyszłe - znajdują się, pre-»egzystują《 w tym maluteńkim teraz i nie plamią, nie brudzą, nie kalają tego teraz ani jedną sekundą” i najważniejsze zdanie: „Teraz to wieczność. Wieczność to wieczne teraz, wieczne nowe tu i-teraz. Wieczność w wiecznie nowym tu i-teraz wiecznie na nowo się uwiecznia"30. Szansą więc na uratowanie się od przeszłości jest odnalezienie się w „teraz”, a tym samym uchwycenie i zrozumienie wieczności. „Teraz” to nieustanne „nowe”. Wieczność konotuje niepowtarzalność, brak rutyny, odradzające się możliwości, świeżość.

Posługując się do tej pory pojęciami „czas” i „wieczność”, warto rozszerzyć znaczenia tych pojęć na podstawie kolejnych fragmentów Stachury. We Wszystko jest poezja próbował on je rozważać nie tylko w filozoficzny, ale także quasi-na-

\footnotetext{
${ }^{28}$ B. Pascal, op. cit.

${ }^{29}$ E. Stachura, Fabula rasa..., s. 64.

${ }^{30}$ Ibidem, s. 66.
} 
ukowy sposób. Robił to za pomocą „pętli zdań” — jedno zdanie modyfikował na kilka sposobów, aby jak najprościej wyłuskać sens czytelnikowi, tak jak w pierwszym fragmencie odnoszącym się do wieczności:

Wieczność albo nie zawiera w sobie żadnego określenia, albo zawiera wszystkie. Tak jak w jednym przypadku: nie ma określenia, jak w drugim przypadku: są wszystkie określenia, nieskończoność określeń — wieczność jest nieokreślona ${ }^{31}$.

Punktem wyjścia jest zatem wieczność. Stachura na początku zakłada, że wieczność jest nieokreślona, nie ma końca ani początku, ale w zamian ma środek bądź środki. Nie jesteśmy w stanie wskazać momentu, kiedy wieczność się zaczyna ani kiedy się skończy. „Zastajemy” ją w trakcie trwania, stąd ów „środek”. Jako że nie znamy wieczności, możemy w stosunku do niej używać wszystkich określeń. Abstrakcyjna część naszej rzeczywistości wymaga nie tylko abstrakcyjnego myślenia, lecz także abstrakcyjnego języka. Trudno taki stworzyć, korzystając z korpusu słów codziennych. Zarówno każde określenie, jak również jego brak, wyraża nieokreśloność wieczności. Stachura pisze dalej w „opowieści-rzece”:

A czy można mówić o początku określonej wieczności? Jeżeli wieczność nie zawiera w sobie żadnego określenia, to niemożliwe jest wyobrazić sobie, skąd określenie mogłoby się pojawić. Jeżeli zaś wieczność zawiera w sobie wszystkie określenia, to można założyć coś takiego, że oto jedno określenie w jakiś sposób zdobywa przewagę nad pozostałymi, mówiąc obrazowo: wysuwa się nad poziom. Można wtedy mówić o początku określenia, które pojawiło się w środku nieokreślenia. Czyli coś się zaczyna z tego, co się nie kończy: ze środka. Coś się nie kończy: wieczność, i jednocześnie coś się zaczyna (na przykład czas. [...]) $)^{32}$.

Barbara Czochralska tak to thumaczy:

Jeżeli przez określoną wieczność będziemy rozumieli wieczność subiektywną, czyli świadomość człowieka, to posiada ona nie tylko początek (czasu), ale również koniec, oglądany z jakiejś innej, zewnętrznej perspektywy — być może z perspektywy innej wieczności, wieczności nieokreślonej ${ }^{33}$.

Dla niej istniałyby zatem dwie wieczności: określona i nieokreślona. Jeżeli wieczność jest określona, to może być tylko rozpatrywana z punktu widzenia człowieka i jego świadomości. Wieczność nieokreślona wychodzi poza świadomość. „Stachura wie, że w wieczności nieokreślonej nie może żadnego określenia zabraknąć, ale nie wie, jak by to można uzasadnić w rozumowaniu (albo może zobaczyć). To był problem, z którym nie mógł sobie poradzić [...]"34.

Niewątpliwie pojawia się w tych fragmentach czas, który przedstawiony jest jako coś istniejącego w ramach wieczności. Wewnątrz. Stachura nie pozostawia tego pomysłu bez dalszych wyjaśnień i konstruuje taką myśl:

${ }^{31}$ E. Stachura, Wszystko..., s. 238.

32 Ibidem

${ }^{33}$ B. Czochralska, op. cit., s. 158.

34 Ibidem, s. 159. 
Bo czas to jest dokładnie nie to co można by mówić o wieczności bez czasu w domyśle, bez tego, co dokładnie czasem nie jest, a co przyjęło się nazywać wiecznością? Nie można by. Jeżeli wieczność to środek bez początku i końca, to można by powiedzieć, że czas to początek i koniec bez środka. W takim razie jeżeli czas się kończy, to co z wiecznością? Przerwa w wieczności, nim się znowu zacznie czas? Tak nie można mówić. Nie ma przerwy, kiedy nie ma czasu. A poza tym i przede wszystkim nie można mówić, że czas się kończy, bo to jest tylko połowa zdania. Nie można też mówić, że czas się zaczyna, bo to jest też tylko połowa zdania. Kiedy czas się zaczyna, to jednocześnie się kończy, ponieważ nie ma środka. Kiedy czas się kończy, to jednocześnie się zaczyna, bo nie ma przerwy, kiedy nie ma czasu. Gdyby wyobrazić sobie wieczność jako linię ciągłą (może być spiralna), lub może lepiej jako brak linii, to czas byłby linią złożoną z punktów ${ }^{35}$.

Pierwsze zdania wyrażają dość prostą rzecz: czas jest przeciwieństwem wieczności. I na odwrót. Wieczność nie ma początku i końca, ale ma środek. Zastajemy ją tylko w momencie nieprzerwanego, permanentnego trwania, co zostało już wcześniej wspomniane. Natomiast tylko w odniesieniu do czasu jesteśmy w stanie wskazać początek i koniec. Jeśli zaś czas istnieje w ramach wieczności, to jego koniec nie oznacza przerwy w wieczności. To jest to, o co chodzi Stachurze później - czas to punkt. Czas nie ma środka, ponieważ czas może się tylko kończyć, a nie „być”. Skoro wieczność jest nieokreślona, to czas, przeciwnie, jest określony. Oba pojęcia definiowane są na zasadzie przeciwstawienia. Barbara Czochralska interpretowała tok rozumowania Stachury podobnie:

Stachura chciał wieczność objąć myślą. Czym jest wieczność? Wieczność nie jest terminem filozoficznym ani naukowym. Wieczność należy do człowieka, wyrasta z jego ciała. Porównana do czasu, jako jego przeciwieństwo, ucieka z tego porównania, prześlizguje się i znika w nieskończoności, która egzystuje w mózgu człowieka. Wieczność nie może być linią. Wieczność jest przestrzenią $^{36}$.

Wieczność może i nie jest terminem filozoficznym, ale na pewno Stachura stworzył swoją filozofię wokół niej. Michał Januszkiewicz odczytuje te wszystkie próby definiowania i filozofowania poety w ten sposób: „Nie będzie przesady, jeśli stwierdzę, iż takie odczuwanie czasu (czy może pozaczasu, wieczności) nie jest niczym innym, jak tylko świadectwem wrażliwości religijnej Stachury"37. Niemniej jednak ciekawe jest to, że w swoich literackich rozważaniach Stachura nigdy nie powołuje się na żadną religię ani Boga. Cały ten konstrukt filozoficzny o śmierci i wieczności uplasował poza jakimkolwiek teologicznym rozumowaniem. Ostatecznie w taki sposób podsumowuje omawiane zagadnienia:

Żeby mogło być wieczyście (tak jak to widzi ten, który tu próbuje to wyjaśnić), ktoś musi nieustannie się pojawiać i znikać, ktoś musi pisać listy albo samemu być tym listem, tym liściem, co jesienią znika z drzewa i pojawia się na wiosnę. Być może to jedyna szansa muskania prawdziwej wieczności w tym czasowym życiu, zanim się zniknie i nie wiadomo pod jaką postacią powróci, jeżeli się powróci. Szansa dla nas i być może, być może dla tejże wieczności. Wygląda tak, że wieczność ma się tak do czasowego życia jak przestrzeń ma się do wędrowcy, jak poezja ma się do

\footnotetext{
${ }^{35}$ E. Stachura, Wszystko..., s. 245.

${ }^{36}$ B. Czochralska, op. cit., s. 155.

${ }^{37}$ M. Januszkiewicz, op. cit., s. 104.
} 
poety. Można łagodnie powiedzieć, że mało widoczne są te pierwsze bez tych drugich. Powiedziałbym dalej łagodnie, że mało jest realności bez zjaw. Jeżeli poezja jest realnością, poeta jest zjawą ${ }^{38}$.

Stachura wyprowadza z pojęcia „wieczność” formę „wieczyście”, odpowiadającą ziemskiemu życiu. To taka „bardziej dostępna” wersja prawdziwej wieczności. Jedyna, na jaką na tym świecie można sobie pozwolić. „Wieczyście” oznacza tutaj „powtarzalnie”, ponieważ autor Siekierezady podaje przykłady pojawiających się na wiosnę liści oraz korespondencji. Liście wracają na drzewach co roku, a listy nieustannie się wysyła, choćby po długim czasie milczenia. Jest to tym samym także próba „prawdziwej wieczności”. Drugą część tego fragmentu przedstawił Stachura, używając porównań, z których wynika, że istota wieczności uwidacznia się w skontrastowaniu jej z określonym w czasie życiem.

To filozofia oswojenia lęku przed końcem. Wiara w niezłomność naszego losu. Autor Wszystko jest poezja konstruuje pomysł „być” bez uwzględnienia jakiegokolwiek czasu, bez definitywnego końca. Warto zauważyć, że Stachura ciekawie się sytuuje z tą koncepcją między chrześcijaństwem a ateizmem. Z jednej strony nie powtarza starych frazesów mówiących, że śmierć jest tylko bramą, przejściem, a nawet początkiem czegoś nowego itp. $Z$ drugiej strony nie ma u niego żadnego końca towarzyszącemu śmierci. Stachura pokazuje, że „nie ma nic”, uwzględnia permanentne trwanie. Tym samym jest to próba optymizmu - zobaczyć coś, przed czym odczuwa się strach, w innym lepszym świetle.

\section{Bibliografia}

\section{Literatura podmiotu}

Stachura E., Cała jaskrawość, Toruń 2012.

Stachura E., Fabula rasa. Z wypowiedzi rozproszonych, red. H. Bereza, Z. Fedecki, K. Rutkowski, t. 5, Warszawa 1984.

Stachura E., Opowiadania, Toruń 2012.

Stachura E., Siekierezada, Toruń 2011.

Stachura Edward, Sie, Warszawa 1978.

Stachura Edward, Wiersze, Toruń 2002.

Stachura Edward, Wszystko jest poezja. Opowieść-rzeka, red. H. Bereza, Z. Fedecki, K. Rutkowski, t. 4, Warszawa 1984.

\section{Literatura przedmiotu}

Wydawnictwa zwarte

Al-Araj A., Twórczość prozatorska Edwarda Stachury w świetle tradycji literackiej i filozoficznej, „Pamiętnik Literacki” 108, 2017, z. 4.

${ }^{38}$ E. Stachura, Wszystko..., s. 253. 
Bereza H., Życiopisanie, [w:] E. Stachura, Fabula rasa, t. 5, Warszawa 1982.

Buchowski M., Buty Ikara. Biografia Edwarda Stachury, Warszawa 2014.

Czochralska B., Ktoś spoza planety. Spotkania z Edwardem Stachura, Kraków 2014.

Fedecki Z., Moda na Stachurę, [w:] Kaskaderzy literatury. O twórczości i legendzie Andrzeja Bursy, Marka Hłaski, Haliny Poświatowskiej, Edwarda Stachury, Ryszarda Milczewskiego-Bruna, Rafała Wojaczka, red. E. Kolbus, Łódź 1986.

Iwińska G., Próba własnej filozofii we „,Wszystko jest poezja” Edwarda Stachury „Prace Literackie” 58, 2018.

Januszkiewicz M., Od egzystencjalizmu do mistyki: o prozie Edwarda Stachury, „Pamiętnik Literacki" 85,1994 , z. 4.

Kiedrowski K., „Fabula rasa” Edwarda Stachury jako literackie wskazanie na źródtowe rozumienie bycia, „Sensus Historae” 2018, nr 2.

Sporne postaci polskiej literatury współczesnej. Następne pokolenie, red. A. Brodzka, L. Burska, Warszawa 1995.

\section{Źródła internetowe}

https://ilemnietoja.pl/nerwica/bajka-o-kwiecie-paproci/ [dostęp: 11.08.2019].

http://www.instytut-perswazji.pl/artykuly/tajemnica-slowa-nie [dostęp: 27.08.2019].

Pascal B., Myśli, przeł. T. Boy-Żeleński, https://wolnelektury.pl/katalog/lektura/pascal-mysli.html

[dostęp: 2.09.2019].

\section{Death delayed indefinitely. Edward Stachura philosophizing on time, death and eternity}

Summary

The article Death delayed indefinitely. Edward Stachura philosophizing on time, death and eternity is an attempt to read Stachura from a different side than as a poet, bard and mediocre singer. It is a compilation of the writer's various texts, but the leading one is a little-known work called Everything is poetry. The story-river (edited by H. Bereza, Z. Fedecki, K. Rutkowski, vol. 4, Warsaw 1984). Stachura transforms into almost a sage, into a philosopher who tries to create elementary definitions of the world, people, time and eternity. He believes that there is no such thing as "nothing" like death, which would mean the definitive end. Thus, he proves that he is not only an "extreme" creator, but one who seeks hope and gaps in describing and understanding the world. The writer attempts to describe eternity, to visualize it, to grasp death as a transition from the „non-ourform-life" to, it seems, a better place. He even changes the forms of talking about eternity - he uses the invented appropriate verb, the infinitive "to be", which does not take into account the existence of any time. This is the term "perpetual time". There is no place to distinguish the present, future or past, because eternity is a "measure", we always find it in the moment of lasting. Therefore, eternity has no beginning or end, unlike time. These concepts of Stachura mainly dictate fear to the end. Thus, he tries to reformulate the common patterns in thinking about death and passing away. Ultimately, it is a study of broadly understood optimism of Stachura, underestimated in his work on a daily basis.

Keywords: philosophy, Edward Stachura, poetry, poet, eternity, time, immortality, sensitivity, human, poem, emotionality, everything 